
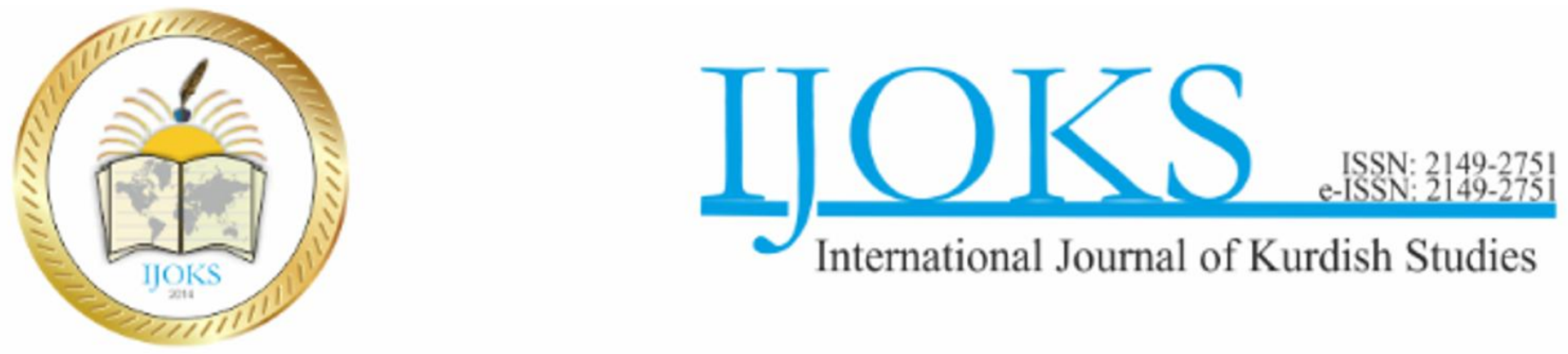

Article

International Journal of Kurdish Studies

6 (2), pp. 202-221

http://ijoks.com

\title{
A Case Study on the Eating Habits of a Selection of University Students in Northern Cyprus
}

\author{
Mehmet Necati CIZRELIOGULLARI ${ }^{1}$ id, Rukiye KILILI ${ }^{2}$ id \& Pinar BARUT $^{3}$ (D)
}

Received: June 07, 2020

Reviewed: June 19, 2020

Accepted: Jul 04, 2020

\begin{abstract}
The aim of this qualitative case study is to examine changes in the eating habits of university students living with their families after starting their tertiary education. Stress or lack of time at university can have adverse affects leading to unhealthy changes in diet. We have accordingly assessed the dietary-related habits of undergraduate students in various departments of EMU. Six Cypriot students, as well as three Iraqi Kurdish students were selected since to date there have been few such studies about Kurdish students. A limitation of this study is that all the respondents were living in Famagusta City in Northern Cyprus; other studies might be conducted in perhaps Nicosia and abroad.
\end{abstract}

Keywords: Kurdish students in Famagusta City, Cypriot students eating habits, Eastern Mediterranean University (EMU) Northern Cyprus, a qualitative case study on undergraduate diet

\section{Recommended citation:}

Cizreliogullari, M.N., Kilili, R. \& Barut, P. (2020). A Case Study on the Eating Habits of a Selection of University Students in Northern Cyprus. International Journal of Kurdish Studies 6 (2), 202 - 221, DOI: https://doi.org/10.21600/ijoks. 748995

\footnotetext{
${ }^{1}$ Assist. Prof. Dr., Faculty of Tourism, Department of Tourism and Hotel Management, Cyprus Science University, Kyrenia, North Cyprus, E-mail: mehmetcizreliogullar@csu.edu.tr, ORCID ID: 0000-0002-9884-6084

${ }^{2}$ Assoc. Prof. Dr. Faculty of Tourism, Department of Tourism and Hotel Management, Cyprus Science University, Kyrenia, North Cyprus, E-mail: rukiyekilili@ csu.edu.tr, ORCID ID: 0000-0002-2049-6432

${ }^{3}$ Ph.D. Candidate, Faculty of Tourism, Eastern Mediterranean University, Famagusta, Northern Cyprus, E-mail: pinarbarut@windowslive.com, ORCID ID: 0000-0002-3624-1581
} 


\section{INTRODUCTION}

Eating habits are important for good health. Diseases due to poor diet can kill regardless of age; obesity and the absolute opposite, anorexia, are to be avoided. Care should be taken in general about eating habits. Eating habits take hold at the start of our lives and affect the wellbeing of individuals in the long-term (Johansen et al. 2006). Studying at university is an important time of life that affords an opportunity to choose a good diet, and develop good eating habits (Colić Barić et al., 2003). According to Bull (1998), young adults do not sufficiently exert themselves by way of finding out how to shop for the kitchen, or how to cook. In recent years, poor eating habits and unhealthy behavioral patterns among university students have been widely reported in various countries (Huang et al., 1994; Kremmyda et al., 2008). Poor eating habits can lead to multiple health problems for young adults when they start their university life; during their study, they face stress and have limited time to cook (Rubina et al., 2009). Such factors act as a hindrance to their receptivity to sound practices; moreover, poor dietary patterns make them receptive to substance abuse (Nelson et al., 2008). Despite the practices of undergraduates being viewed as transitory, "just" a feature of university life - undesirable propensities show themselves and for the most part persist in their seasoned adulthood (Silliman et al., 2004; Boyle and LaRose, 2009). Analysts have discovered that dietary changes and the length of time correspond with issues in new situations, as for example: the capacity of migrants to talk or take in a new dialect; their social contact with individuals of the new culture; and more obvious is their inclusion in extracurricular events and instructive projects. It is thought that more youthful foreigners, by and large are prone to change their nourishment propensities more promptly than seasoned workers (Kim et. al., 1984; Deshpande et al., 2009). Men are more likely to change their nourishment propensities than women, since the latter have more experience in rounding up what they are accustomed to eat (Gupta, 1975). Researchers have found evidence that significant ailments are linked to eating habits (Young and Fors, 2001; Trichopoulou et al., 2003). Thus, Yahia, Achkar et al. (2008) and Johansen et al. (2006) states that the fast food sector has a bad effect on the eating habits of adolescents. Despende et al. (2009) states that when old enough to choose their own food their future healthiness or vice versa is largely determined, and this option often presents itself at university age. According to Marquis (2005), unfortunately students tend to evolve bad eating habits at this critical time. In a study 
conducted in 2004, the American University of Health Association (2006) revealed that only $7.3 \%$ of university students eat fruit and vegetables.

It is in our youth that lifelong habits become settled. As regards university students, their attitudes toward eating can be affected by multiple factors such as their personal thoughts and perception of their own bodies, as well as genetic factors, their lifestyle, habits and so on. All such factors affect the individual's choice of healthy or unhealthy behaviors (Oğur and Aksoy, 2016; Racette et al., 2005; Fritz et al., 2019). There has been no previous study investigating the eating habits of local and Kurdish university students at EMU despite the importance of the issue of eating habits. The education students receive at university is formative; it molds their identities in the ongoing process of their education and strengthens the basis of their beliefs and attitudes. This present study examines changes in the dietary habits of university students from the start of their university education to the aftermath of their studies; the aim is to assess their eating habits to see whether or not they are more healthy or less healthy, or just the same. One might say that this study is at the same time an assessment of the dietary-related habits of young adults.

\section{REVIEW OF THE EXISTING LITERATURE}

Students may confront the pressure of social adjustment and segregation due to their living conditions and consequently a need to find ways of satisfying their need for nourishment and to adapt to the shorter or longer haul of their stay abroad (Constantine et al., 2005). It is only possible to have a vague idea concerning the extent of adaptation of temporary residents such as external students in regard to the diverse nourishment and dietary conditions - how they see changes in their diet, and what the fundamental determinants are of their dietary propensities in their host conditions (Perez-Cueto et al., 2009).) Work suggests that the strategies they devise may also promote healthy behavior in their participation across a wide range of domains such as physical activity, sleep quality and cessation of smoking (Black et al., 2015; Cooke et al., 2014; Lowe and Norman, 2013; Johansen et al., 2006). Recent research has shown that positive psychological approaches can be especially beneficial in promoting healthy dietary changes (Colić Barić et al., 2003; Perez-Cueto et al., 2009). Seeing things from a diverse point of view, rather than focusing on concern about how their eating behavior is seen by others is an inspiration for dodging eating related ponderables and might possibly result in an outburst of self-imposed objectives or eating aspirations (O'Reilly et al., 2014). Avoiding conditions positing a desire to indulge in unhealthy food or overeating is 
widely recommended as a self-control mechanism and is related to the positive self-control recommended as a self-control strategy (Gillebaart and de Ridder, 2015; Hofmann et al., 2012). University students with low self-efficacy in eating healthily - those who tend to eat in reaction to palatable food signals, or who have overwhelming or unpleasant food thoughts, they may resist engaging in eating-related studies because they do not want to put themselves in a position where they have less influence over their food intake. Moreover, those who endeavor to limit their nourishment to oversee their bodyweight may dodge taking part in eating-related investigations seeking to maintain a strategic distance from an introduction to enticement that undermines their objective (Van Haynes and Robinson, 2019; Kremmyda, et al., 2008; Lowe and Norman, 2013).

Many researches have shown that university students often have poor eating habits, in general eating less fruits and vegetables and increasing their intake of high-fat, high-calorie foods. (Brevard and Ricketts, 1996; Driskell et al., 2005; Racette et al., 2005). As per the American University Health Association (2006), a recent report revealed that a lone $7.3 \%$ of undergraduates eat at least five servings of foods grown from the ground day-by-day. Progress in their studies frequently compounds the dietary propensities of undergraduates (Grace, 1997) that could lead to additional weight issues particularly during a decisive year at school or university and continue throughout their later life (Anderson et al., 2003; Centers for Disease Control, 1997; Racette et al., 2005). Educating consumers in more sustainable nourishment choices and eating propensities within the nourishment framework may lead to behavior changes. University undergraduates are an interesting target population since, at this stage of reorientation in their lives, they shape their character and establish their convictions and demeanors (Vermeir and Verbeke, 2008; Monroe et al., 2015).

Eating behaviors university undergraduate sectors have been cited as contrasting going by sex and living choices (El Ansari et al., 2011, 2012; Papadaki, 2007). Moreno-G'omez et al. (2012) states that a detailed calorie count shows the quantity to be higher in females, while El Ansari et al. (2011) suggests that consumption of natural products and vegetables and consumption of sweets especially chocolate is higher among female undergraduates. El Ansari et al. (2011) and Papadaki et al. (2007) found that undergraduates living away from the parental domestic environment had poorer eating propensities. Al-Nakeeb (2015) and Dodd (2010) comment that one wonders if according to the author's information there is more than one sign of eating behavior. Burke (1997) and Vries et al. (2008) state that despite the existence of proofs illustrating that wellbeing and life-style behaviors can coexist, few undergraduates take notice. 
Other studies in the literature have shown that there is a link between the dietary behavior and demographic and psychographic characteristics of university students. Driskell et al. (2005) showed that there is very little difference in nutritional habits between the lower and higher level students, which indicates that habits established in the first or second year may progress to later university years (Deshpande, 2009). However, it seems that a student's place of residence affects dietary habits and diet-related health. (Brevard and Ricketts, 1996). Among other factors associated with poor eating habits is especially stress (Cartwright et al., 2003) and a low level of self-confidence (Huntsinger and Luecken, 2004). Past researches have brought to light data on diets low wholesome foods (Barr, 1984; Van cave Reek and Keith, 1984), but absence of information on hunger as related to dependence on finances means there is insufficient data about nourishment (Thomsen et al., 1987). According to Grace (1997), eating habits often deteriorate during university years, but many university students acquire these food habits in a natural way (Driskell et al., 1979). Factors exposing students to nutritional risk, especially financial problems, include meal reduction (Nicklas et al., 2001), limitation in food diversity (Pinto and Marcus, 1995; Huang et al., 1994; Evans et al., 2000), snacking (Nicklas et al., 2001), and frequent fast food consumption (Hertzler, 1995). There is also a rapid decline in physical activity, particularly between the ages of 18 and 24 (Grubbs and Carter, 2002; Stephens et al., 1985); most university students have a sedentary lifestyle (Pinto and Marcus, 1995).

The eating behavior of individuals can change over the years in accord with their experiences and adoption of the life-style of the university, and undergraduates are a vital population to target for advancement of sound eating behaviors; this is because they are on the move from being cared for by their families to free adulthood (Boyle and LaRose, 2009; Kim et al., 2012). Laying the foundation for sound eating habits at this point will likely lead to their long term wellbeing with a diminished chance of developing corpulence and other nourishment related illnesses (Anderson et al., 2003; Constantine et al., 2005). In addition, it is anticipated that superior nourishment and wellbeing will empower undergraduates to maximize their appreciation of their studies and executive abilities (Gores, 2008). Hence, universities have a social obligation to their undergraduates to openly fund, back and advance sound eating behaviors (Brevard and Ricketts, 1996). Influences leading to sound eating, both external and internal, in recent times have been successfully theorized into viable methodologies. External and internal influences leading to sound eating habits and other behavior bringing about wellbeing have been examined through the lens of a number of hypothetical systems (Deshpande et al., 2009; Driskell et al., 1979, 2005). The common 
conclusion of such theorizing is that influences bringing about sound eating habits are complex and interrelated. Be that as it may, an understanding of aspirations and fundamental convictions or demeanors has been singled out as key to affect the behaviors that bring about wellbeing (Lowe and Norman, 2013). Wellbeing in undergraduates indicates the visible benefits of healthy eating and limits to solid eating - both having noteworthy impact on behavior patterns. A significant recognition of the benefits of healthy eating is the moot cognizance of obstructions creating the drive to eagerly eat sound nourishing foods (Kim et al., 2012). The age and stage of life of undergraduates is decisive in regards to long-term outcomes such as corpulence, which is inevitable if there are no positive behavioral changes (Nelson et al., 2008). Shoppers have the opportunity to advance wellbeing as a result of endeavors to purchase nutritious food, which hearkens back to their self-efficacy - their certainty in their adherence to sound eating behaviors (Blotnicky et al., 2015).

As a researcher once stated, there are a variety of opinions about the relationship between weight gain and eating behavior. The "escape theory" explains how this relationship works. Individuals, due to the state of their emotions may have cravings for excessive eating; this is called emotional eating and this situation occurs in psychologically distressed situations. This is because they develop the mechanism to deal with distress automatically utilizing the sensation of eating. (Heatherton and Baumeister, 1991; Aldao and Schweizer, 2010). According to Dalen et al. (2010), the relationship between obesity and eating disorders is generally contextualized with anxiety and stress, especially depression. Here, we look at the model of obesity disorder, the individual's lack of power-of-restraint and hunger as the cause of failure to regulate eating behavior (Craighead and Allen, 1995). On the other hand, as Bruch (1964) says, psychosomatic theory stems from the inability to comprehend whether the individual is physically hungry or otherwise stimulated in response to excessive eating emotions. If we look at another theory, according to the theory of externality, people are sensitive to external foods and therefore, have the sensation of over-eating (Schacter and Rodin, 2014). Daubenmier et al. (2011) and O'Reilly (2014) investigate these theories, and find a common direction. According to them, problematic eating behaviors are linked to incompatible connections with internal and external reactions. Such problems generally do not include weight gain or loss, or interventions for weight loss that are restricted to food types. 


\section{METHODOLOGY}

\subsection{Case Location}

EMU is considered to be the best university in North Cyprus. It is the biggest and most popular international university in North Cyprus. It is in the top rankings of the UKbased Times Higher Education (THE), one of the most reputable publishers of worldwide university rankings, announced as "The World's Best Young Universities Rankings 2019" (also known as 'Under 50 Rankings'), featuring the list of the world's best universities under the age of 50. EMU is also among the top five universities in Turkey. It is ranked fourth among Turkish universities after Sabancı University, Koç University and Bilkent University. EMU is followed by Atılım University which obtained fifth place amongst Turkish universities. Theft and crime rates in Cyprus are much lower than in other countries, which encourages students to study at EMU. Many foreign students from various countries have the chance to settle down in Famagusta with their families, either parents or a spouse, until graduation.

\subsection{Data Collection}

The present research uses the case study method. Eisenhardt (1989), an important name in case study method recommends this type of study to predict new hypotheses and facilitate analysis of data estimation. Based on his explanation, we can say that a case study helps to better understand the subject and opens the way to deeper study. Although there are sources claiming that the case study can be done both qualitatively and quantitatively, it should be quantitative if aiming for generalization (Yin, 1994). However, quantitative case study can also be more important to understand the subject deeply (Stake, 1995). The case study carried out in this framework is conducted qualitatively. The qualitative method has been used in the present study. Rather than seeking to generalize, it strives to delve deep. The data is collected through interviews in accordance with the qualitative method and the participants were asked semi structured questions. This type of case study could also have been done with open-ended questions, but I had neither sufficient time nor knowledge; I chose this method to avoid mistakes. Since the participants were students, they were selected by the snowball sample technique. There were nine participants in all. Six were Cypriot and three were Iraqi Kurdish students from different departments. They were age 18 to 26 . Six were female, and four were male. For reasons of confidentiality, their names were not revealed. The initial interview was on 3 January 2020, the last day of lectures. I chose that day because after the conclusion of lectures they would be more relaxed and more able to focus on my 
questions. The location for interviews was always at the university, and there were others roundabout.

Table 1: Respondent Information

\begin{tabular}{|l|l|l|l|l|l|}
\hline Participants & Age & Gender & Department & Year & Location \\
\hline Participant 1 & 26 & Female & Tourism & 3rd & Famagusta \\
\hline Participant 2 & 24 & Female & Sport Sciences & 7 th & Famagusta \\
\hline Participant 3 & 25 & Male & Psychical Training Teacher & 7 th & Famagusta \\
\hline Participant 4 & 22 & Male & International Trade and Business & 4 th & Famagusta \\
\hline Participant 5 & 18 & Male & Sports Sciences & 1 st & Famagusta \\
\hline Participant 6 & 20 & Male & Sports Sciences & 2nd & Tuzla \\
\hline Participant 7 & 19 & Female & Molecular biology and genetic & 1 st & Famagusta \\
\hline Participant 8 & 23 & Female & Accounting & 3rd & Yeniboğaziçi \\
\hline Participant 9 & 20 & Female & Business & 2nd & Famagusta \\
\hline
\end{tabular}

\subsection{Interview Process}

The respondents were informed about the aim of the research, and they were aware that their name would not be used anywhere. The respondents actively answered the questions during the interview. They interpreted their feelings and they even added more information to the questions. All of the oral interviews were recorded, and then they were all transcribed, even laughs or pauses. The questions were asked in two different languages: Kurdish and English. Although the Iraqi Kurdish students knew English, they wanted to have the interview in Kurdish. I think they felt more secure in their mother tongue. The average duration was 2-3 minutes, the maximum 5 minutes.

\section{FINDINGS}

Thus, the qualitative method was used with coding management. Interviewing was the preferred means, and all the interviews and transcription processes were carried out by the researchers. The findings are analyzed and explained in the present study. The answers obtained from the interview questions intended to acquire the needed information were categorized as a result of the coding system. The eating habits of the subject undergraduate students were noted. The coding chosen for these students for the first interviews were subdivided under three headings: Eating Place / Health Outcome / Comparing with Earlier Life (comparison with their lives before they started university). In Table 1 above, the information characterizing each of the participants has been provided. 


\subsection{Coding}

The first stage of coding was open coding. Open coding examines the details in the data and helps to categorize them. Again, as stated open coding not only categorizes but also reveals features and dimensions (Strauss and Corbin, 1990). Conducting this study in line with these frameworks, the open coding method was applied, subdivided into categories and subtitles were created. The next step was axial coding, and with this method, the categories discussed in open coding were linked (Johnson, 2015). Selective coding, which is the last stage, provides the necessary integration to collect all categories in axial coding and form theory (Johnson, 2015). Coding analysis, which is an important part of our qualitative study, was thus accomplished. The categories and the responses given by the participants are shown in Table 2 below:

Table 2. Selective Coding

\begin{tabular}{|c|c|c|c|}
\hline & Eating Place & Health Outcome & Comparing with Early Life \\
\hline P. 1 & $\begin{array}{l}\text { If there is no time, I } \\
\text { prefer to eat out ... }\end{array}$ & $\begin{array}{l}\text { I have gained weight but it has not } \\
\text { affected my health as yet }\end{array}$ & It was much better. \\
\hline P. 2 & Home. & $\begin{array}{l}\text { No, I haven't faced any health } \\
\text { problems after starting university. }\end{array}$ & It was the same. \\
\hline P. 3 & Burger city. & It affects. & $\begin{array}{l}\text { Mostly at home because after school I } \\
\text { used to go home. That's why. }\end{array}$ \\
\hline P. 4 & Usually at home. & Yes, it affects. & $\begin{array}{l}\text { Ready food (he meant to say fast food) } \\
\text { generally. }\end{array}$ \\
\hline P. 5 & At home & Yes. & Again, at home \\
\hline P. 6 & At home & Yes. & Usually, I ate out. Fast food \\
\hline P. 7 & $\begin{array}{l}\text { I always eat my mom's } \\
\text { dishes. }\end{array}$ & $\begin{array}{l}\text { No, I don't face any health } \\
\text { problem. }\end{array}$ & $\begin{array}{l}\text { I was a student at a private school and so } \\
\text { I had to stay at school till } 4 \text { o'clock. I } \\
\text { preferred my lunches from my schools' } \\
\text { cafeteria. They were like homemade } \\
\text { food. So there was no difference from } \\
\text { now. }\end{array}$ \\
\hline P. 8 & Mostly at restaurants. & $\begin{array}{l}\text { Yes, most probably it affects but I } \\
\text { haven't been faced with any health } \\
\text { problem till now. }\end{array}$ & $\begin{array}{l}\text { It was more regular and there were more } \\
\text { homemade foods ... }\end{array}$ \\
\hline
\end{tabular}




\begin{tabular}{|l|l|l|l|}
\hline P.9 & $\begin{array}{l}\text { Usually I go to my } \\
\text { home. }\end{array}$ & It affects. & There was more fast food. \\
\hline
\end{tabular}

\section{RESULTS}

In this part of the study the answers of the students will be taken into consideration. They explain too much information about their eating habits. There are some similarities but there are some differences as well. All the participants think that eating at home or eating homemade meals is healthy; on the other hand, some of them say that they would rather eat at home than eat out. The rest say that to the contrary they wish to eat out in preference to having homemade food.

Results from the interviews categorized under the three subtitles of Table 2 (Eating Place / Health Outcome / Comparing with Earlier Life) are considered one by one below:

\subsection{Eating Place}

While finding out about the place where the students choose to eat when feeling hungry, there were two different answers: - either a house or a restaurant. There were no other options such as for example bringing food home. The students choosing the house for eating say that it has been easy to go home and eat. However, the important point is that dishes cooked by their mothers are the most delicious. This point comes to light in the following interview with Participant 1:

Me: When you feel hungry, where do you prefer to eat?

$$
\text { P. D.: At home }
$$

Me: Why?

P. D.: Because my mother always makes delicious food. I can't find any meal outside like what she makes. It's important to me to have the meals she prepares.

Participant 2 was 24 years old. This was her 7 th year of study at university and still she may not attempt to go home to eat. In point of fact, it might be hard for her to eat at home, judging by when E.G. said:

When I feel hungry, I would usually choose to eat at home. But if I don't have anything prepared and ready at home and I am very hungry, I call a pizza place or junk food 
restaurant for a take away or even go there. If I don't have time I prefer eating out, but if I have time I prefer homemade food.

It is easy to say that based on E.G.'s answer, it is not always possible to go home. She is the oldest participant of my research; she is a candidate for the Ph.D. The part of the research reveals that most of the students prefer eating at home; only two prefer eating out. One of the participants lives in Yeniboğaziçi village, and she prefers eating at restaurants in Famagusta. The other one surprisingly prefers fast food instead of going home even though he is in the department of "Sport Sciences" and his house is in Famagusta which is where the university is located.

\subsection{Health Outcome}

In this part of the research, the students said that eating at home is healthier than eating out. They agree that eating dishes made by their mothers helps them to be healthy. Furthermore, apart from two respondents, the others said that they did not put on or lose weight to an extent that was worrisome during their university education, and they attributed this to their eating their mother's home cooked meals. Both women said that they gained weight during their education. One of them partially eats out, and the other is the student always eating out. I questioned her:

Me: Have you gained or lost weight during your education?

A. A.: I gained weight because I always ate at restaurants, most of the time I had fast-food. I know that it is not healthy and I know that I gained weight because of it but I had to go to such places. I didn't have time to go home and eat. Being a student is not easy (laughs).

She is a third-year student and she is 23-years-old. We can understand that her time is limited. But it is important to understand that eating out makes some changes in the body of the students. The others do not have the same problem. Four female and four male students said that they did not put on or lose weight because of their eating habits. They believed that their eating behavior was important for being healthy. To give an example:

Me: Why do you choose to eat at home?

E. A.: Because it is healthy, I don't want to eat harmful food. I should be careful about my body shape and health. I always have my mom's dishes and I don't have any health problem, so why should I eat some other food? 
She is 19-years-old and she believes that having her mother's food is healthier than eating out. That is why she goes to her village "Yeniboğaziçic" every day to eat. Moreover, when I asked a question about weight, she said: "I didn't put on or lose any weight. And I again asked: Do you think it is related to your eating habits?" She said: "Exactly. Yes." When I asked the same question to the most senior woman in my research, she gave the same answer. Moreover, when we consider the boys, they believe the same thing as the women do. For example, O. K. says: "I prefer to eat at home because then I don't have any health problems. I didn't gain or lose any weight at the end of my university education." He is the youngest participant. To sum up, they all believe that their body and mind are healthy because of their eating behavior and they all agree that eating well will prevent them from having health problems.

\subsection{Comparing with early life}

I wanted to explore whether or not there was any change from before or after university, so I asked some more questions. Again, there were similar answers; some of them told me that they saw no change after their high school and were happy about that. On the other hand, the rest of the respondents said that they had had different eating habits at high school and these habits had changed at university. One of them had been a student at a private school and she said that she had homemade food at their school and she is still goes home for meals so there is no change for her. The respondents saying that they had had the same eating habits before university had gone on eating at home. For example, P.D. said: "I ate homemade food while I was in high school." This is her 7th year at university and she still prefers eating at home in the same way as she did at high school. She said that she was and is happy with this eating habit. On questioning the youngest respondent once more, we find that he used to prefer homemade dishes and even now after completing his university studies he prefers eating at home. When I checked to see how our oldest respondent was faring, she said:

E.G.: Things are much better. I have paid more attention to my health. I rarely eat out, maybe only on Mondays when I have to stay on at school for an hour. Other than that, I always eat at home and I have kept healthy.

She had had to change her eating habits while engaging in university life because of her lectures and education schedule. 
All in all, we note two basic changes. First, some of them were eating at home during their high school life and at university had started to eat out. Second, they had been eating out but at university started to eat at home. If we consider the respondents who ate out at university, we find that they were eating more fast-food when they were young. For example:

D.T.: Now I prefer mother's food instead of eating out. It's healthier. I ate fast food when I was at high school. At that age, I didn't realize the difference. But now I know, and that's why I go home to eat.

The other participant with habits similar to hers was A.K. He said: "I generally preferred to eat out and had fast food when I was at high school." His answer regarding his post-university lifestyle was quite the opposite. Now, at the age of 22, he prefers eating at home. My 20-yearold respondent S.D. said he too had preferred eating out instead of eating at home but he said that he had changed this habit and had started to eat at home with a view to staying healthy. The last two respondents related that they used to eat at home when they were at high school but had changed this habit when they started university. A.A., the female student living a little away from Famagusta said: "I preferred eating at home when I was at high school but at the university I couldn't get home to eat." She said that she had not been happy with her habits. Again A.A.: "I know it's not healthy but (she paused), but I prefer to eat out." K.H. a very young man said that at present he prefers eating out: "I used to prefer to eat at home when I was at high school, but now I eat out. I don't have a car to go out or anywhere else for that matter (he laughs)." From these remarks, we gather that when we compare their eating habits with their earlier life, there are three different groups. In the first group, there is just one student and she was a private school student; she ate homemade food, and she is going home again to have homemade food. In the second group, the students affected changes in their habits in order to become healthier. They had been eating out before starting university but changed this habit in favor of eating at home; they now prefer their mother's dishes. The third and last group also changed their eating habits; they had been accustomed to eating at home during their high school years, but after commencing university study, no longer preferred to go home to eat.

\section{DISCUSSION AND CONCLUSION}

This study shows that most of the Cypriot and Kurdish students regardless of gender prefer eating at home in Famagusta. They have the opportunity to eat their mother's food 
instead of eating at restaurants or ordering fast food delivered to their home. Let us again consider previous literature such as Kremmyda et al., (2008), Gores (2008), Sajwani et al. (2009), and Richardson et al. (2015). They all state that international university students develop a greater yen for snacks or high-calorie food. Our findings tell us that students in the current case study go home for meals with pleasure. Moreover, only two out of nine students prefer to eat outside and of the two, one prefers to eat at home but sometimes she does not have that opportunity. The remaining seven students prefer to eat at home every day. They find their mother's food more delicious and healthier. They go home for meals despite their being enrolled in intensive courses, which means that they cultivate eating habits. Surprisingly, all the students interviewed said that they did not have a health problem due to eating patterns. One student reported having a chronic disease. In the final analysis, they all believed that eating their mother's cooking would make them healthier individuals. If we look for evidence supporting their overall trust in their mother's cooking, we find that the students who habitually ate out said they had gained weight. According to Katsounari (2009) and Katsounari and Zeeni (2012), Cypriot female students are concerned about weight loss or gain. Moreover, students eating their mother's dishes had stated that they did not experience any serious weight loss or gain. We can conclude that this is somehow related to the Mediterranean culture. Mediterranean dishes use plenty of olive oil, and plenty of fruit and vegetables (Keys,1970). Trichopoulou et al., (2003) states that the Mediterranean eating culture prevents obesity and it does not induce cancer. Niehoff (2009) stated that fast food has increased obesity rapidly all over the world. Moreover, obesity is a dangerous disease and also brings other diseases. The biggest advantage of being a native student is being able to eat mom's dinners. Worthy of note is that students prefer to take advantage of this opportunity. Regardless of their preferences, they choose to eat at home when they commence their university life. This may be related to the fact of university students becoming aware that they should behave like adults and pay attention to their health. In contrast to students studying in their own country, Greek researchers have found that students studying abroad have great difficulties with diet (Papadaki et. al., 2007). According to Bull (1988), students studying abroad struggle with shopping for food. In this case study, the Cypriot students do not have to do the shopping. Their family would do the shopping. Finding their food ready could be a good reason for their preferring to eat at home. Students from abroad would have to do their own cooking to have their customary food which could be why they choose to eat out. It might take time or it might be boring. The Kurdish students in this case study had the 
opportunity to eat at home. They said that that was their preference for health reasons, but without that opportunity they might have been less concerned about their health.

To sum up, this study aims to investigate the eating habits of some university students after they started university. It was found that most of the students preferred to go to their families / homes for dinner in a study conducted with the students living in and around Famagusta. Thus the students studying at Eastern Mediterranean University stated that eating with their families led to a healthy diet, and therefore they did not have any health problems. They did not experience any serious weight loss or gain which means that the Kurdish students were healthier than those studying elsewhere who could not participate in family meals. Another result to be drawn from this study is that students preferred their mothers' cooking during their university years even if during their high school years they had eaten with their families as well as outside. It is evident that they had made a decision for the sake of healthy living after they reached a conscious age.

\section{LIMITATION AND FUTURE RESEARCH RECOMMENDATION}

In the literature on international students, researchers stated that university students experience many difficulties and face health problems. However, Eastern Mediterranean University students stated that they did not face such problems. This case study has thus thrown new light on the literature at large and shown that it is necessary to conduct innovative research on the health status of Kurdish students. There were some limitations to this study, mainly that the number of interviews were not sufficient to reach a valid conclusion. The interviews were conducted by an interviewer who generally lives in the vicinity of the Eastern Mediterranean University. Similar case studies should also be conducted for students from other cities such as Nicosia, Kyrenia or Güzelyurt in Northern Cyprus. Another limitation was that although younger undergraduate students in Cyprus participated, they gave very short answers and as a result their questionnaires may have had invalid results. Therefore, although the resultant determinations are deemed correct, the analysis could be improved upon. Relative to future research, this study was qualitative, but not quantitative. Quantitative studies should also be done to target a wider audience. Problematic discoveries should be examined in more detail and answers obtained from a larger arena; this case study was conducted only at Eastern Mediterranean University. Even in Northern Cyprus there are many more universities. 


\section{References}

Aldao, A., Nolen-Hoeksema, S., \& Schweizer, S. (2010). Emotion-regulation strategies across psychopathology: A meta-analytic review. Clinical psychology review, 30(2), 217- 237.

Al-Nakeeb, Y., Lyons, M., Dodd, L., \& Al-Nuaim, A. (2015). An investigation into the lifestyle, health habits, and risk factors of young adults. International journal of environmental research and public health, 12(4), 4380-4394.

American University Health Association. (2006). American university health associationnational university health assessment (ACHA-NCHA) Spring 2004 reference group data report (abridged). Journal of American University Health, 54(4), 201.

Anderson, D. A., Shapiro, J. R., \& Lundgren, J. D. (2003). The freshman year of university as a critical period for weight gain: an initial evaluation. Eating behaviors, 4(4), 363-367.

Barr, S. I. (1987). Nutrition knowledge of female varsity athletes and university students. Journal of the American Dietetic Association, 87(12), 1660-1664.

Black, D. S., O'Reilly, G. A., Olmstead, R., Breen, E. C., \& Irwin, M. R. (2015). Mindfulness meditation and improvement in sleep quality and daytime impairment among older adults with sleep disturbances: A randomized clinical trial. Journal of the American Medical Association Internal Medicine, 175, 494-501.

Blotnicky, K. A., Mann, L. L., \& Joy, P. R. (2015). An Assessment of University Students' healthy Eating Behaviors With The Expectancy Theory. Asbbs E-Journal, 11(1), 31.

Boyle, J. R., \& LaRose, N. R. (2009). Personal beliefs, the environment and university students' exercise and eating behaviors. American Journal of Health Studies. 23 (4), 194-201.

Brevard, P. B., \& Ricketts, C. D. (1996). Residence of university students affects dietary intake, physical activity, and serum lipid levels. Journal of the American Dietetic Association, 96(1), 35-38.

Bruch, H. (1964). Psychological aspects of overeating and obesity. Psychosomatics, 5(5), 269-274.

Bull, N. L. (1988). Studies of the dietary habits, food consumption and nutrient intakes of adolescents and young adults. World Review of Nutrition and Dietetics.

Burke, V., Milligan, R. A. K., Beilin, L. J., Dunbar, D., Spencer, M., Balde, E., \& Gracey, M. P. (1997). Clustering of health-related behaviors among 18-year-old Australians. Preventive medicine, 26(5), 724-733.

Cartwright, M., Wardle, J., Steggles, N., Simon, A. E., Croker, H., \& Jarvis, M. J. (2003). Stress and dietary practices in adolescents. Health psychology, 22(4), 362.

Centers for Disease Control and Prevention. (1997). Youth risk behavior surveillance: National university health risk behavior survey United States, 1995 Morbidity and Mortality Weekly Report. Surveillance Summaries, 46(6), 1-54.

Colić Barić, I., Šatalić, Z., \& Lukešić, Ž. (2003). Nutritive value of meals, dietary habits and nutritive status in Croatian university students according to gender. International journal of food sciences and nutrition, 54(6), 473-484.

Constantine, M. G., Anderson, G. M., Berkel, L. A., Caldwell, L. D., \& Utsey, S. O. (2005). Examining the cultural adjustment experiences of African international university students: A qualitative analysis. Journal of Counseling Psychology, 52(1), 57.

Cooke, R., Trebaczyk, H., Harris, P., \& Wright, A. J. (2014). Self-affirmation promotes physical activity. Journal of Sport and Exercise Psychology, 36, 217-223.

Craighead, L. W., \& Allen, H. N. (1995). Appetite awareness training: A cognitive behavioral intervention for binge eating. Cognitive and Behavioral Practice, 2(2), 249-270. 
Dalen, J., Smith, B. W., Shelley, B. M., Sloan, A. L., Leahigh, L., \& Begay, D. (2010). Pilot study: Mindful Eating and Living (MEAL): weight, eating behavior, and psychological outcomes associated with a mindfulness-based intervention for people with obesity. Complementary therapies in medicine, 18(6), 260-264.

Daubenmier, J., Kristeller, J., Hecht, F. M., Maninger, N., Kuwata, M., Jhaveri, K., ... \& Epel, E. (2011). Mindfulness intervention for stress eating to reduce cortisol and abdominal fat among overweight and obese women: an exploratory randomized controlled study. Journal of obesity, 1-13.

Deshpande, S., Basil, M. D., \& Basil, D. Z. (2009). Factors influencing healthy eating habits among university students: An application of the health belief model. Health marketing quarterly, 26(2), 145-164.

Dodd, L. J., Al-Nakeeb, Y., Nevill, A., \& Forshaw, M. J. (2010). Lifestyle risk factors of students: a cluster analytical approach. Preventive medicine, 51(1), 73-77.

Driskell, J. A., Keith, R. E., \& Tangney, C. C. (1979). Nutritional status of white university students in Virginia. Journal of the American Dietetic Association, 74(1), 32-35.

Driskell, J. A., Kim, Y. N., \& Goebel, K. J. (2005). Few differences found in the typical eating and physical activity habits of lower-level and upper-level university students. Journal of the American Dietetic Association, 105(5), 798-801.

Eisenhardt, K. M. (1989). Building theories from case study research. Academy of management review, 14(4), 532-550.

El Ansari, W., Stock, C., \& Mikolajczyk, R. T. (2012). Relationships between food consumption and living arrangements among university students in four European countries-a cross-sectional study. Nutrition journal, 11(1), 28.

El Ansari, W., Stock, C., John, J., Deeny, P., Phillips, C., Snelgrove, S., ... \& Mabhala, A. (2011). Health promoting behaviours and lifestyle characteristics of students at seven universities in the UK. Central European journal of public health, 19(4),197-204.

Evans, A. E., Sawyer-Morse, M. K., \& Betsinger, A. (2000). Fruit and vegetable consumption among Mexican-American university students. Journal of the Academy of Nutrition and Dietetics, 100(11), 1399.

Fritz, M. M., Armenta, C. N., Walsh, L. C., \& Lyubomirsky, S. (2019). Gratitude facilitates healthy eating behavior in adolescents and young adults. Journal of Experimental Social Psychology, 81, 4-14.

Gillebaart, M., \& de Ridder, D. T. (2015). Effortless self-control: A novel perspective on response conflict strategies in trait self-control. Social and Personality Psychology Compass, 9(2), 88-99.

Gores, S. E. (2008). Addressing nutritional issues in the university-aged client: Strategies for the nurse practitioner. Journal of the American Academy of Nurse Practitioners, 20(1), $5-10$.

Gores, S. E. (2008). Addressing nutritional issues in the university-aged client: Strategies for the nurse practitioner. Journal of the American Academy of Nurse Practitioners, 20(1), 5-10.

Grace, T. W. (1997). Health problems of university students. Journal of American University Health, 45(6), 243-251.

Grubbs, L., \& Carter, J. (2002). The relationship of perceived benefits and barriers to reported exercise behaviors in university undergraduates. Family \& Community Health, 25(2), 76-84.

Gupta, S. P. (1975). Changes in the Food Habits of Asian Indians in the United States: A Case Study. Sociology and social research, 60(1), 87-99.

Haynes, A., \& Robinson, E. (2019). Who are we testing? Self-selection bias in laboratorybased eating behavior studies. Appetite, 104-330. 
Heatherton, T. F., \& Baumeister, R. F. (1991). Binge eating as escape from self-awareness. Psychological bulletin. 110(1), 86.

Hertzler, A. A., Webb, R., \& Frary, R. B. (1995). Over consumption of fat by university students: the fast food connection. Ecology of food and nutrition, 34(1), 49-57.

Hofmann, W., Baumeister, R. F., Förster, G., \& Vohs, K. D. (2012). Everyday temptations: an experience sampling study of desire, conflict, and self-control. Journal of personality and social psychology, 102(6), 1318.

Huang, Y. L., Song, W. O., Schemmel, R. A., \& Hoerr, S. M. (1994). What do university students eat? Food selection and meal pattern. Nutrition Research, 14(8), 1143-1153.

Huntsinger, E. T., \& Luecken, L. J. (2004). Attachment relationships and health behavior: The mediational role of self-esteem. Psychology \& Health, 19(4), 515-526.

Johansen, A., Rasmussen, S., \& Madsen, M. (2006). Health behaviour among adolescents in Denmark: influence of school class and individual risk factors. Scandinavian Journal of Public Health, 34(1), 32-40.

Johnson, J. S. (2015). Qualitative sales research: An exposition of grounded theory. Journal of Personal Selling \& Sales Management, 35(3), 262-273.

Katsounari, I. (2009). Self-esteem, depression and eating disordered attitudes: A crosscultural comparison between Cypriot and British young women. European Eating Disorders Review: The Professional Journal of the Eating Disorders Association, 17(6), 455-461.

Katsounari, I., \& Zeeni, N. (2012). Preoccupation with weight and eating patterns of Lebanese and Cypriot female students. Psychology, 3(06), 507.

Keys, A. (1970). Coronary heart disease in seven countries. Circulation, 41(1), 186-195.

Kim, H. S., Ahn, J., \& No, J. K. (2012). Applying the Health Belief Model to university students' health behavior. Nutrition research and practice, 6(6), 551-558.

Kim, K. K., Kohrs, M. B., Twork, R., \& Grier, M. R. (1984). Dietary calcium intakes of elderly Korean Americans. Journal of the American Dietetic Association, 84(2), 164169.

Kremmyda, L. S., Papadaki, A., Hondros, G., Kapsokefalou, M., \& Scott, J. A. (2008). Differentiating between the effect of rapid dietary acculturation and the effect of living away from home for the first time, on the diets of Greek students studying in Glasgow. Appetite, 50(2-3), 455-463.

Lowe, R., \& Norman, P. (2013). Attitudinal approaches to health behavior: Integrating expectancy-value and automaticity accounts. Social and Personality Psychology Compass, 7(8), 572-584.

Marquis, M. (2005). Exploring convenience orientation as a food motivation for university students living in residence halls. International journal of consumer studies, 29 (1), $55-63$.

Monroe, J. T., Lofgren, I. E., Sartini, B. L., \& Greene, G. W. (2015). The Green Eating Project: web-based intervention to promote environmentally conscious eating behaviours in US university students. Public health nutrition, 18(13), 2368-2378.

Moreno-Gómez, C., Romaguera-Bosch, D., Tauler-Riera, P., Bennasar-Veny, M., PericasBeltran, J., Martinez-Andreu, S., \& Aguilo-Pons, A. (2012). Clustering of lifestyle factors in Spanish university students: the relationship between smoking, alcohol consumption, physical activity and diet quality. Public health nutrition, 15(11), 21312139.

Nelson, M. C., Story, M., Larson, N. I., Neumark-Sztainer, D., \& Lytle, L. A. (2008). Emerging adulthood and university-aged youth: an overlooked age for weight-related behavior change. Obesity, 16(10), 2205-2211. 
Nicklas, T. A., Baranowski, T., Cullen, K. W., \& Berenson, G. (2001). Eating patterns, dietary quality and obesity. Journal of the American University of Nutrition, 20(6), 599-608.

Niehoff, V. (2009). Childhood obesity: A call to action. Bariatric Nursing and Surgical Patient Care, 4(1), 17-23.

Oğur, S., \& Aksoy, A. (2016). Üniversite Öğrencilerinin Yeme Davranışı Bozukluğuna Yatkınlıkları: Bitlis Eren Üniversitesi Örneği. Bitlis Eren Üniversitesi Fen Bilimleri Dergisi, 5(1), 14-26.

O'Reilly, G. A., Cook, L., Spruijt-Metz, D., \& Black, D. S. (2014). Mindfulness-based interventions for obesity-related eating behaviours: a literature review. Obesity reviews, 15(6), 453-461.

Papadaki, A., Hondros, G., Scott, J. A., \& Kapsokefalou, M. (2007). Eating habits of university students living at, or away from home in Greece. Appetite, 49(1), 169-176.

Perez-Cueto, F., Verbeke, W., Lachat, C., \& Remaut-De Winter, A. M. (2009). Changes in dietary habits following temporal migration. The case of international students in Belgium. Appetite, 52(1), 83-88.

Pinto, B. M., \& Marcus, B. H. (1995). A stages of change approach to understanding university students' physical activity. Journal of American University Health, 44(1), 27-31.

Racette, S. B., Deusinger, S. S., Strube, M. J., Highstein, G. R., \& Deusinger, R. H. (2005). Weight changes, exercise, and dietary patterns during freshman and sophomore years of university. Journal of American university health, 53(6), 245-251.

Richardson, T., Elliott, P., Waller, G., \& Bell, L. (2015). Longitudinal relationships between financial difficulties and eating attitudes in undergraduate students. International Journal of Eating Disorders, 48(5), 517-521.

Rubina, K., Kalinina, N., Efimenko, A., Lopatina, T., Melikhova, V., Tsokolaeva, Z., ... \& Parfyonova, Y. (2009). Adipose stromal cells stimulate angiogenesis via promoting progenitor cell differentiation, secretion of angiogenic factors, and enhancing vessel maturation. Tissue Engineering Part A, 15(8), 2039-2050.

Sajwani, R. A., Shoukat, S., Raza, R., Shiekh, M. M., Rashid, Q., Siddique, M. S., ... \& Kadir, M. M. (2009). Knowledge and practice of healthy lifestyle and dietary habits in medical and non-medical students of Karachi, Pakistan. Journal of the Pakistan Medical Association, 59(9), 650.

Sajwani, R. A., Shoukat, S., Raza, R., Shiekh, M. M., Rashid, Q., Siddique, M. S., ... \& Kadir, M. M. (2009). Knowledge and practice of healthy lifestyle and dietary habits in medical and non-medical students of Karachi, Pakistan. Journal of the Pakistan Medical Association, 59(9), 650.

Schacter, S., \& Rodin, J. (2014). Obese humans and rats. Lawrence Erlbaum, Routledge.

Silliman, K., Rodas-Fortier, K., \& Neyman, M. (2004). Survey of dietary and exercise habits and perceived barriers to following a healthy lifestyle in a university population. Californian journal of health promotion, 2(2), 10-19.

Stake, R. E. (1995). The art of case study research. Sage.

Stephens, T., Jacobs Jr, D. R., \& White, C. C. (1985). A descriptive epidemiology of leisuretime physical activity. Public health reports, 100(2), 147.

Strauss, A., \& Corbin, J. (1990). Basics of qualitative research. Sage publications.

Thomsen, P. A., Terry, R. D., \& Amos, R. J. (1987). Adolescents' beliefs about and reasons for using vitamin/mineral supplements. Journal of the American Dietetic Association, 87(8), 1063-1065. 
Trichopoulou, A., Costacou, T., Bamia, C., \& Trichopoulos, D. (2003). Adherence to a Mediterranean diet and survival in a Greek population. New England Journal of Medicine, 348(26), 2599-2608.

Van den Reek, M., \& Keith, R. E. (1984). Knowledge and use of United States dietary goals by university students. Nutrition reports international (USA).

Vermeir, I., \& Verbeke, W. (2008). Sustainable food consumption among young adults in Belgium: Theory of planned behavior and the role of confidence and values. Ecological economics, 64(3), 542-553.

Vries, H. D., Kremers, S., Smeets, T., \& Reubsaet, A. (2008). Clustering of diet, physical activity and smoking and a general willingness to change. Psychology \& health, 23(3), 265-278.

Yahia, N., Achkar, A., Abdallah, A., \& Rizk, S. (2008). Eating habits and obesity among Lebanese university students. Nutrition journal, 7(1), 32.

Yin, R. K. (1994). Discovering the future of the case study. Method in evaluation research. Evaluation practice, 15(3), 283-290.

Young, E. M., \& Fors, S. W. (2001). Factors related to the eating habits of students in grades 9-12. Journal of School Health, 71(10), 483-488. 